THURSDAY, AUGUST 14, I89o.

\section{THE INCOME-TAX AND THE PROMOTION OF SCIENCE.}

THE case of the Commissioners of Inland Revenue v. Forrest (the latter representing the Institution of Civil Engineers), which was finally decided on the Ist inst. by the House of Lords, is of great importance to all scientific corporations, associations, and institutions in this country, and, incidentally, the judgments cannot fail to interest, and possibly also to amuse, men of science, because it became necessary for their Lordships to consider what is science, or, rather, what the Legislature meant by the word science in a particular statute. Shorn of all technicality, the question was whether the Institution of Civil Engineers was liable to pay incometax under the Revenue Act of I 885 , section II of which was framed with the object of imposing a duty of 5 per cent. on the yearly value, income, or profits of bodies which escape probate, legacy, and succession duties, inasmuch as they never die and have no legal heirs or successors. The net was thrown with the object of catching trading corporations, companies, and associations, and compelling them to pay, in the shape of an annual impost, an equivalent for the various death duties levied on private individuals. The Act imposing this tax, however, exempted different classes of associations, and notably in sub-section 3 of section I I it exempted all property the income or profit of which is applied for religious or charitable purposes, "or for the promotion of education, literature, science, or the fine arts." The whole question therefore resolved itself into this: Is the Institution of Civil Engineers an association "for the promotion of science"? The Commissioners thought it was not, in the sense used in the Act; Lord Coleridge and Mr. Justice (now Lord) Field sitting in one Court agreed with the Commissioners ; Lord Justice Lopes in the Court of Appeal, and the Lord Chancellor in the House of Lords, were of the same opinion; but Lord Esher and Lord Justice Fry in the Court of Appeal, and Lord Watson and Lord Macnaghten in the House of Lords, held that the Institution was one for the promotion of science, and therefore exempt from the tax. The Institution therefore had a majority of the judges in the Court of Appeal and in the House of Lords, and it is now the law of England, until the Legislature chooses to alter it, that the Institution and all similar associations and bodies are exempt from this tax. Science, and, indeed, literature and the fine arts as well, owe a debt of gratitude to the Institution for its sturdy stand against the demand for payment. Although it is successful, its costs, over and above what it will receive from the Crown as the losing party, would, if invested, probably yield an income sufficient to satisfy the demand made upon it ; by continuing the fight it has been the means of relieving the revenues of every association of the kind in the country from a burden of 5 per cent. per annum, an impost which in some cases would be intolerable, and would perhaps lead to the extinction of many struggling associations which are worthy of more support than they receive. In a sense, all science is relieved of a tax, and this it owes to the Institution of Civil Engineers.

NO. IO85, VOL. 42]
We have said that the question turned on the meaning to be attached to the phrase "promotion of science," and ultimately to the word "science." The consideration of this question was complicated by the circumstance that in I843 an Act was passed for dealing with the application of local rating (the Act of 1885 , which was in question in this case, dealt wholly with Imperial taxation) to "exclusively" scientific and literary institutions supported wholly or in part by voluntary contributions. Under this Act it has been decided, for example, that the Zoological Society and the Russell Institution are liable to local rates, and it was against decisions such as these, and the instinct of judges to seek for a precedent, that the Institution of Civil Engineers had to fight in the present instance. Lord Macnaghten, however, boldly threw over the Act of 1843 and the decisions under it altogether, and refused to regard them as throwing any light on the Act of 1885 . It referred, he said, merely to local rates, exemption from which is an invidious distinction, and throws a burden on everyone in the neighbourhood; while the present case being one of Imperial taxation, the range of exemption is far more extensive, and the conditions far more liberal.

The previous statute, and all the decisions under it, being thus disposed of, the judges were deprived of precedents, and had to answer for themselves what was science in the intention of the Legislature in 1885 . Most intelligent people have a satisfactory working definition of the word; but it evidently perplexed the keen and experienced legal intellects of the judges in the House of Lords. The Lord Chancellor thought it could not, in this place, be equivalent to knowledge, because this would exempt almost every institution in the country, but that it did refer to science generally, and not to any particular branch of it. The Institution was, he argued, established for the benefit and interest of civil engineers, and not directly (though, no doubt, indirectly) for the advantage of the whole community. "I think a member of it makes a vèry good bargain for himself in becoming a member of it," and hence he did not regard it as exempt from taxation. Lord Watson took quite a different view, without going largely into questions of definition. It was indisputable, he said, that there was a science of civil engineering, that its development is of the utmost consequence to the national interests, that the labours of the Institution are of value to the profession at large, and constitute a substantial addition to the sum of human knowledge, and that it would be difficult to say what more effective measures could be adopted for the promotion of engineering science than those of the Institution. He found, therefore, that the latter applied its income, not to the professional ends of individuals, but for " the promotion of science," and that it was entitled to the exemption. Lord Macnaghten faced the question of the meaning of the word "science" in the Act :-

"I see no reason why it should be confined to pure or speculative science. The expression plainly includes applied science, and it was intended, I think, to denote a particular branch of science, as well as universal science or science generally."

This being his view, Lord Macnaghten, like Lord Watson, found no difficulty in arriving at the conclusion 
that the Institution of Civil Engineers did in fact promote science :-

"Substantially, as it seems to me, the whole of the Society's income is applied to the promotion of science. My Lords, I cannot conceive in what better way the promotion of mechanical science, and in particular of those branches of mechanical science which lie within the province of civil engineering, could be effected. I cannot doubt that by means of the discussions on the papers read at the ordinary meetings of the Society much new light has been thrown on scientific questions, and much knowledge, which would otherwise have perished, has been preserved. I see no trace of a selfish or illiberal spirit in the proceedings of the Society, nor do I find anything to lead me to suppose that its property and income are applied otherwise than bon $\hat{a}$ ' fide for the promotion of science. The action of the Society may incidentally benefit the profession to which its members belong-I have no doubt that is so-but I agree with the Master of the Rolls in thinking that 'that which this Society does is something higher and larger than the mere education of students and others for the profession of civil engineers.' "

The admirable definition of the object of the Institution, embodied in the charter of 1828 , was stated in the course of one of the judgments to have been drafted by Thomas Tredgold. The Institution, it says, is established for the purpose of

"the general advancement of mechanical science, and more particularly for promoting the acquisition of that species of knowledge which constitutes the profession of a civil engineer, being the art of directing the great sources of power in nature for the use and convenience of man, as the means of production and of traffic in States both for external and internal trade, as applied in the construction of roads, bridges, aqueducts, canals, river navigation, and docks, for internal intercourse and exchange, and in the construction of ports, harbours, moles, breakwaters, and lighthouses, and in the art of navigation by artificial power for the purposes of commerce, and in the construction and adaptation of machinery, and in the drainage of cities and towns."

It is only right to say, in conclusion, that the utility of the work done by the Institution was admitted in the warmest manner by those judges who found themselves compelled to decide against its claim to exemption, now happily established.

\section{PRINCIPLES OF ECONOMICS.}

Principles of Economics. Vol. I. By Prof. Alfred Marshall. (London: Macmillan and Co., I89o.)

$\mathrm{G}$ CONOMICS admit of being reduced to principles E more than other sciences dealing with human actions, for the reason which Prof. Marshall has thus expressed: "Wide as are the interests of which the economist takes account when applying his doctrines to practice, the centre of his work is a body of systematic reasoning as to the quantities of measurable motives." These measurable motives are not necessarily self-interested : "The range of economic measurement may gradually extend to much philanthropic action." Even now the supply of labour and of capital is largely due to the motive of family affection. The uniformities of action resulting from such measurable motives may be regarded as the laws of motion in what Jevons called the mechanics of NO. IO85, VOL. 42$]$ industry--a science which Prof. Marshall has cultivated with more success than any of his predecessors, owing to an unexampled combination of antithetical powers, the comprehensive grasp of mathematical reasoning, and the carcful handling in detail of the observed facts.

As in physical mechanics innumerabie conditions may be comprehended under the principle of virtual velocity, so also there is a unifying principle in the mechanics of industry. "Most economic problems have a kernel relating to the equilibrium of demand and supply." It is the peculiar merit of Prof. Marshall's arrangement to treat the law of supply and demand generally, before applying it to particular "markets," such as that relating to labour. It is here that he differs most from Mill, who seems to put asunder what the nature of things has joined together under one law-distribution and exchange. If Prof. Marshall's conception does not come as a surprise to his readers, it must be considered that he himself, in published and unpublished writings, has prepared the scientific world to accept his view. The services of others, particularly Prof. Walras, in improving upon the old wooden conception of distribution are not to be forgotten. Still it is true that, as far as we know, Prof. Marshall is the first adequately to treat what he has elsewhere called the pure theory of domestic (as opposed to international) value; uniting in a comprehensive view the doctrine of final utility, which Jevons and other recent writers have made prominent, with the equally eternal verities relating to "cost of production," which are connected with the name of Ricardo. The "theorems of Ricardo and Marshall" are rightly coupled by Signor Pantaleoni in his masterly "Principii di Economia Pura."

The relation between cost of production and demand is thus expressed by Prof. Marshall, following Cournot.

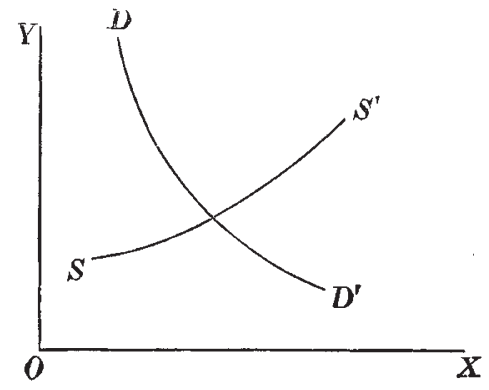

In the annexed diagram the abscissa indicates the amount of a product, and the ordinate the price thereof. $\mathrm{DD}^{\prime}$ is the demand curve, representing the quantity of the product which is demanded at each price; $\mathrm{SS}^{\prime}$ the supply curve, representing the quantity which is offered at each price. The intersection of these curves determines the equilibrium of the market-a generic term used in a wide sense, covering the temporary equilibrium of a fish-market and those slow processes of competition which it requires a generation to work out.

From this point of view is apparent the inaccuracy of those who describe value as altogether an affair of final utility, and speak of Ricardo as being "preposterous" in the classic sense of putting the cart before the horse. To use our own illustration, these economists might be compared to a physicist who should insist that in the determination of the position at which a balloon reaches 